\title{
The politics of service delivery in South Africa: The local government sphere in context
}

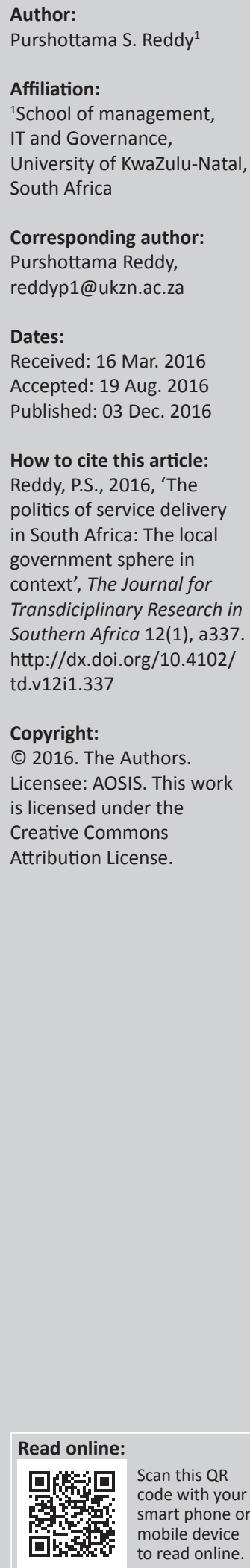

\begin{abstract}
The post-1994 democratic developmental South African state opted for a strong local government system which has been constitutionalised, in terms of Chapter 7 of the Constitution of the Republic of South Africa Act 108 of 1996. The politicisation of the local bureaucracy was inevitable as the ruling party sought to ensure that the executive leadership of municipalities shared the same political ideology and vision to facilitate local development. This raises the question, where does politicisation commence and end, and what is the ideal local political interface for efficient and effective service delivery and, more importantly, to ensure good governance? These questions have to take cognisance of the fact that South Africa is a 'struggle democracy' and development has to take place in historically disadvantaged areas, where services have been poor or non-existent. The historically advantaged areas have to also be maintained and upgraded, as they are key to financial sustainability of the municipalities. The increasing service delivery protests is a matter for concern, if one has to take cognisance of the popular adage highlighted in official literature, 'if local government fails, South Arica fails'. Given that the struggles for a democratic South Africa were fought at the grassroots level, this has to translate to an improved quality of life for local communities. Consequently, sound political management is key to enhanced municipal service delivery and ultimately good local governance. This paper reviews political trends and developments up to 2016, but excludes any discussion on the recent local government elections.
\end{abstract}

\section{Introduction}

Globally, the term service delivery is a popular phrase that is used to denote the distribution of basic communal needs and services, notably housing, water and sanitation, land, electricity and infrastructure, which local communities have taken for granted and become dependent on for their daily existence. However, in the South African context, the delivery and ongoing upkeep of these basic services have proved to be unreliable at times, greatly inconveniencing and endangering local communities. The resultant response, particularly in the past decade, has been increasing 'service delivery protests' or protests demanding 'better service delivery' 1 (www.blogs.cfr.org/ cambell/2014/05/15/south-africa-what-does-service-delivery-really-mean/; Booysen 2012a; Dassah 2012; Reddy 2010)

Political infighting and related clashes between the political and management components in local government in South Africa have also adversely affected municipal service delivery. It is a given that the public sector in an African context has always been deemed to be political in nature and South Africa is no exception (Booysen 2012a; Cameron 2003; 2010; De Visser 2010). On a more practical and realistic level, there have also been challenges experienced relative to the politicaladministrative interface at the local sphere. South Africa as a democratic state has only been in existence for just over two decades and is a young democracy (Ndudula 2013:3). The local sphere of government is particularly crucial as it signifies grassroots governance and local democracy, which are considered to be closest to the people, and more importantly, it is at the coalface relative to the delivery of basic services.

This paper critiques the politicisation of local government and the resultant implications for municipal service delivery in the broader context of developmental and good local governance. It also critically reviews the 'cadre deployment' policy of the ruling party, which has generated a great deal of debate and discussion in political, academic and social circles, as such policies have provided the impetus for the election and appointment of senior municipal functionaries in local government in the past two decades. The concluding part of the paper focuses on possible solutions and recommendations as a way of moving forward to address the key thematic issues highlighted.

1.South Africa is viewed in some circles as the protest capital of the world (Tony \& Lei 2010 ; Soony 2006 in Dassah 2012 ). 
The research methodology adopted for this study was a desktop literature review of key trends and developments in the field, drawn from books, journals, official publications, legislation and policies, newspaper articles, websites and dissertations. In addition, there were also focused and structured discussions with high-ranking municipal functionaries and a manager of a non-governmental organisation active in local government in the province of KwaZulu-Natal.

\section{Politics, politicisation and service delivery contextualised in South Africa Conceptual framework: Politics and service delivery}

\section{Politics and politicisation}

Ndudula (2013:6), quoting Hanekom et al., defines politics as being the aspirations for and, more importantly, the retention of power over residents of a particular jurisdiction by certain individuals or groups of individuals. Inherent in the definition is the allocation of values authoritatively in such a manner that it seeks to regulate or accommodate conflicts within the local communities in question. The individuals or groupings will, through a locally defined process, introduce policies and programmes that will enhance the quality of life of their constituents. The process also determines who shall assume local leadership positions and furthermore how power shall be exercised in the municipal jurisdiction. This is viewed in a local government context as the democratic and authoritative allocation of scarce public resources throughout the municipal jurisdiction, with organised governments or grouping having developed a political relationship with one another in the process (Thornhill 2012:57). Thornhill (2012), quoting Walsh, Fox and Meyer, points out that it is important to refer to politics as a basic and critical process in the public sector as it not only implies party politics but also politics as part of a wider decisionmaking process, that is, questions relative to who receives what, when and where, in a service delivery context at the local level. It is a conflict resolution process which ultimately determines resources distribution, that is, who decides which power and influences are to be taken cognisance of; whether and how governmental power is to be exercised; and the apportionment of values in a defined state, region or municipality (Van der Waldt 2014a). The majority grouping in any representative public structure or body is actually responsible for determining political power and defining relationships. In this context, it should be noted that power is not the domain of any single individual and has to be collectively exercised. Politics is the realm of the politicians and is practised at the local sphere of government by the councillors and the executive component of the council, that is, the mayor, deputy mayor, speaker, chairperson of the executive/standing committee and members of the mayoral committee (Thornhill \& Cloete 2014:76-79; Van der Walt 2014b).

Thornhill (2012:57) points out that although local politics or the political process may appear to be simplistic, it is quite complex as it involves analysing the available factual information on hand, and this has to be done within a particular value framework, defined by a political party or even an interest/pressure group in a defined jurisdiction. Thornhill argues further that local politics involves the attachment of values to factual information, determining the relative importance of requests by society generally or a certain segment for a particular municipal service, and the quantity, quality or extent of services to be delivered locally (2012:58). The Constitution of the Republic of South Africa Act, 1996 (Act 108 of 1996), provides the legal basis for political governance of the country, province, district/metropolitan area or municipal area. ${ }^{2}$ The political component, which is the council at the local level, is responsible for initiating and overseeing the executive actions of officials appointed to act on its behalf in terms of discharging its governmental responsibilities. The council exercises an oversight function over the administrative activities of the municipalities. Section 157 (2) has created space through the proportional representation system for party politics and ultimately political direction in local government (De Visser 2005; Reddy 2010). Shah, in De Visser (2005), believes that the institutional integrity of a government level is undermined if firm political views from centralised structures have to be translated to practice at lower levels.

"Politicisation" is the substitution of political for merit-based criteria in the selection, retention, promotion, rewards and disciplining of members of the service' (Pieters \& Pierre 2004:2). The implication is that the municipal service is governed largely by political considerations, be it in appointments, dismissals or even the delivery of basic municipal services. Consequently, in this context political considerations, to a large extent, will be dictated by the political philosophy of the ruling political party any point in time.

\section{Service delivery}

Service delivery in the context of local government is the provision of municipal goods, benefits, activities and satisfactions that are deemed public, to enhance the quality of life in local jurisdictions. Within this framework, particular reference is being made to the discharging of municipal services, which can either be tangible or intangible. The former refers to the provision of municipal services that are construed as being visible to local communities, such as, inter alia, public housing, roads, water and sanitation systems, and public transport, whilst the latter refers to services that are regarded as being essential, but not necessarily visible, such as public drainage and sewage systems and public safety standards (Ndudula 2013:10). Craythorne, in Nealer (quoted by Reddy \& Naidu 2012), adds a legal dimension to all of this, in that 'a municipal service, ... is a service that a municipality in terms of its powers and functions provides or may provide to or for the benefit of its responsibility area irrespective of whether, ... such a service is provided, ... through an external, ... or, ... internal mechanism' and whether 'fees are levied in respect of such a service or not'. A municipal service deemed basic is 'necessary to ensure an 2.See section $151(3)$ of the Act. 
acceptable and reasonable quality of life and, if not provided, would endanger public health, or safety or the environment ${ }^{\prime 3}$ (Reddy \& Naidu 2012:94). Municipalities are regarded as the custodian of public funds and consequently they have been tasked with utilising these resources to address the basic needs of local communities, notably infrastructure, electricity, water, refuse removal and the spatial development of localities. Govender and Reddy (2012:71) highlighting aspects of the 2008 local government budget and expenditure review argue that local government investment has not yielded the anticipated returns expected from the national economy. They add that collectively, poor governance, inappropriate spatial planning, inadequate social infrastructure and massive service backlogs have emerged as constraints to poverty reduction and economic growth. The resultant effect of these constraining factors is that it could undermine the future sustainability of other key sectors as well (Govender \& Reddy 2012:71).

Service delivery protests originated during the apartheid era in South Africa as they were used as strategies to express dissatisfaction with the lack of services as well as target ethnically based structures. More specifically, the overall goal was to develop community-based structures and social movements to oppose the apartheid system. Alexander, as quoted by Govender and Reddy (2012:72), points out that protests beyond the 1994 local government dispensation can be viewed as expression of needs and grassroots protests against the poor quality of service delivery and related issues. A 'service delivery protest' is 'galvanised by inadequate local services or tardy service delivery, the responsibility for which lies with the municipality' (Allan \& Hesse n.d.). The catchphrase has proved useful in relation to the local government vocabularly as it is used to describe and draw attention to similar incidents occurring locally, provincially and nationally. There is a firm belief in local communities in South Africa that 'voting helps and protest works' when deciding on a proposed course of action in terms of highlighting service delivery deficiencies at the local level (Alexander 2010:29). According to Ramjee and Van Donk (2011:6), the country has been a constitutional democracy for almost two decades and the citizenry believe that it is a reasonable period to reflect on and assess how far it has moved beyond the pre1994 sociopolitical and apartheid legacy. They add that in this context, citizens tend to derive some justification in expressing their dissatisfaction in some tangible way with local governance and more specifically poor service delivery (2011:6). The protests have taken on several different forms, namely, police confrontations, municipal functionaries forced to resign, toyi-toying, mass meetings, submission of memoranda, and petitions, processions, stayaways, chasing unpopular residents out of townships, election boycotts, road blockades, construction of barriers and burning of tyres, and the destruction of property and looting (Alexander 2010:26; Booysen 2012b; Tshishonga 2015:136).

There are several analysts who believe that the service delivery boycotts are basically a rebellion by the poor against neo-liberal policies. The protests seem to be originating and taking place in the poorer neighbourhoods, namely, townships and informal settlements rather than the suburbs (Alexander 2010:26). ${ }^{4}$ Todes (cited in Dassah 2012:2) adds that following the ushering in of a neo-liberal policy framework in 1996, the indigent in South Africa have been increasingly abandoned in favour of economic implications. In this context, the protests at the local level can be viewed as the indigent and marginalised rebelling and at the same time attempting to initiate social change at the grassroots level in terms of improving their lives. Continuing with this line of thinking, Duncan (2009) points out that the Mbeki administration was responsible for the introduction of neo-liberal policies and adds that during that era, protest action was an integral part of political life. It increased during the Zuma Administration, and Williams (cited in Dassah 2012:2) is of the view that the demands for social justice are in essence an opposition to neoliberalism, which to a large extent tends to privatise the basic needs of the citizenry, relying on the ubiquitous market, resulting in the commercialisation of virtually every aspect of society. He added that the discourse on service delivery and public protests generally has also highlighted other issues, such as increasing unemployment, poverty and inequality, especially among black South Africans.

Perhaps the statement made by the then Deputy Minister of Provincial and Local Government, Yunus Carrim (2010) contextualises the discussion and does raise some concerns:

Most of the protests are about service delivery issues. But they are also about a range of other municipal issues including maladministration, nepotism, fraud and corruption and the failure of councillors and administrators to listen to residents. But it is the rage of some sections of the protestors and the extent of violence and destruction that they wreak that is striking. It reflects a far more fundamental alienation of people from our democracy. It suggests an accurate sense of marginalisation and exclusion, ... the nature and scope of the protests we are witnessing are not part of a healthy growing democracy.

Powell (2012:2) reflecting on recent trends and developments points out that local government mirrors the larger political and socio-economic challenges that are shaping South African society. He adds that two decades of policy reform are yet to usher in a new society as envisioned in the Local Government White Paper of 1998. It would appear that the systems in place for local government funding do appear to be insufficient, and the functions delegated to this sphere are quite onerous. However, this is not necessarily the case as the local sphere has several sources of funding which can be tapped. It is imperative that municipal functionaries tasked with financial responsibilities are adequately qualified and have the required technical expertise to access the funding available in the form of grants and subsidies. The politicisation of local government has created a challenge in this regard as the necessary skills at the local level are, at best, marginally available, and the political and management will to take firm and decisive action is lacking (Reddy 2015a; Zybrands 2012:68, 88).

4. Research from Municipal iQs Hotspots clearly indicates that the majority of protests are in informal settlements in the larger metropolitan municipalities and is a regular recurrence (Allan and Heese.n.d.). 
The key question tends to focus on political will, which to a large extent drives the administration and is an integral part of local governance. The local governance system, given the challenges is inadequately designed and at best poorly managed, often by people who are accountable to their political principals rather than the constituents below who are at the receiving end of poor service delivery (Booysen 2012a:7). Local government is key to basic service delivery and, furthermore, can be viewed as the engine of local development. However, as Gumede (cited in Reddy 2010:81) points out a large percentage of the local communities are yet to receive rudimentary services and 'for most township residents the most basic of service delivery, getting a pavement fixed or the rubbish cleared that is piled up on the streets is a distant dream', and this is a matter of concern and has contributed to the dysfunctionality of local government in the past decade.

According to Booysen (2012a:5), one of the major areas of concern for the local communities in South Africa generally is that the local government is in the majority of cases, continuously dysfunctional and is often the unstable coalface of interaction with the people. She points out that it is the (already weak) 'local' sphere that often bears the brunt of dissatisfaction with the national and provincial government as it is in close proximity to local communities. Furthermore, the municipal functionaries and physical facilities of the municipalities are more visible and accessible to the local citizenry. There seems to be more public accountability in local government than at either the provincial or national government level. This together with the mixed electoral system with its own set of dynamics have in fact provided the impetus for much of the dissatisfaction and resultant local protests nationally (Pieterse et al. 2008:20). In fact, it is believed that there are many more opportunities for political deviance and dissent at the local level, rather than targeting national or provincial government which are more remote physically. The reasons for local governments being targeted can be attributed to the following:

- Greater visibility of weaknesses in local governance, notably corruption and maladministration.

- The local bureaucracy and political component is more exposed to the local communities and the electorate.

- Being the target of protests that expose and try to hold to account local politicians and bureaucrats.

- Standing as evidence of institutional underdevelopment and lack of sufficient human capacity.

- Bearing responsibility for the flaws and mistakes of the national and provincial government.

- Provincial and national party leadership manoeuvres to improve (or manipulate) the local representatives (Booysen 2012a:2).

The dysfunctionality of local government in the South African context has assumed several different forms, notably the lack of political and management will to making sound appointments, acting decisively on contentious issues, the failure to pass municipal budgets, the inability to gain qualified audits, and the failure to communicate with local communities and address their needs. There has also been a question mark placed on the quality of local government representation and the perceived accountability of councillors as part of the local citizen interface (Booysen 2012a:5). In the past decade, there have been several interventions ${ }^{5}$ by the national and provincial governments to address this dysfunctionality in local government; however, there has not been any substantial improvement in service delivery (Reddy 2015a).

Municipalities have, in terms of schedules 4 and 5 of the constitution, functions that are explicitly detailed. It would appear that since their establishment they have been discharging their functions with limited funds at their disposal. However, they have not maximised their sources of revenue, collected all revenues due to it or been creative about additional sources of revenue.

Zybrands has also highlighted several other challenges that have impacted negatively on service delivery since the ushering in of the post-1994 local government dispensation, namely:

- Unfunded mandates, where municipalities are not funded or receive very little funding for services such as housing, library services, tourism, welfare services and support for the Commission. ${ }^{6}$

- Financial viability: the demarcation process has resulted in some municipalities not having an economic base and being financially viable (Reddy 2010:82). They are dependent on grants from other spheres of government.

- Legal compliance: there is a compliance-driven governmental approach as opposed to a service delivery one. Quite often, there are First World standards and Third World competencies, resources and needs. It has been difficult for municipalities to comply with prescripts.

- Sound fiscal discipline is not compatible with deficient political leadership. As long as 'cadre deployment' is practiced and municipalities are forced to practice financial discipline, the financial future of municipalities will remain bleak.

- Guiding local economic development to address unemployment and poverty alleviation: there is no money for LED projects and additional work should be channelled to emerging service providers through the supply chain management system (See Reddy \& Wallis 2015b).

- Establishing an investment-friendly environment: through cheap land, concessionary tariffs and tax holidays (Zybrands 2012).

These challenges have been high on the municipal agenda for over a decade and the Government has attempted to respond to these issues but with limited success. It requires firm commitment, a certain level of seriousness and passion by the key role players if more specifically the latter points are to be addressed.

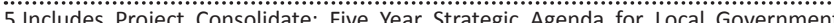
2006 - 2011; Turnaround Strategy for Local Government and the Back to Basics Programme in Local Government.

6.See Reddy (2010 77-78) for a more detailed discussion of this issue. 


\section{The dilemmas of local government politicisation}

The election or appointment of municipal functionaries who are not adequately qualified and based on political patronage and nepotism is a constraint on the efficient and effective performance of local government (Booysen 2012b). In this context, Zybrands (2012:82 and refer also to Tshishonga 2015) cites several examples of what has transpired with regard to senior local government appointments over the years. For example, $\mathrm{X}$ is a school principal, who has been fired for fraud, and has been appointed a municipal manager; $Y$ is a geography teacher who has been appointed a chief financial officer of a municipality; and Z, who does not have any technical skills, is appointed as technical manager after the provincial premier intervened (2012:82) (See also Cameron 2010:686; De Visser 2010:95). Local government has been the sphere where much of the political patronage has taken place with disastrous consequences, particularly for service delivery.

A significant number of municipalities bear ample testimony to the failures of local government and the inability of the ruling party to deliver on improvements despite, a series of interventions and strategies. In this regard, Booysen (2012b:352) points out that 'faltering local government, graphically exposed to policy realisation deficits and multiple cases of overt corruption, mismanagement and inappropriate appointments - often elicits popular disdain. She adds that political reward, patronage and nepotism are some of the key characteristics of local government politics and demonstrable evidence of this locally quite often triggers protest among the local communities. Zybrands (2012:87) points to a possible solution and that is 'the appointment of competent and qualified staff and compliance with the laws, rules and regulations could help solve this conundrum. The question remains whether there is sufficient political will to do so' (refer also to Reddy 2015a). According to Habib (2015), when municipal leaders are challenged on service delivery issues, their most common response privately is 'look at the (poor) quality of the people that I have around me'. He then asks the question, who appointed these people, and adds in a rhetorical response that to disown the appointments one had made, and the consequences thereof, is a manifestation of unaccountable leadership' (2015), which unfortunately has constituted the basis of local government failure in South Africa. There is constant reference by municipal functionaries of 'world class cities', but at the same time the traffic lights are quite often not functioning; the grass on the verges are not regularly trimmed; water pipes are constantly broken or even leaking; portholes are multiplying; telephones are often unanswered and there is widespread urban decay throughout the municipal areas resulting in a depreciation of property values and loss of potential income for the municipalities. The longitudinal implications of the failure to act decisively and the negative impact it is likely to have on sustainable local government has not yet fully registered with the municipal functionaries.
President Zuma, speaking at a South African Local Government Association (SALGA) Conference, urged municipalities to appoint competent staff and added that there should be no compromise on ensuring that officials have the necessary qualifications. He criticised municipal functionaries who hired family or friends with no skills, saying 'don't employ people because you feel for them or they are your friend or cousin. Employ people to do work' (Times 25 March 2015). He also questioned the use of consultants who were paid a total of more than R30 billion in the 2013 and 2014 financial year. He pointed out that 'if those of us who are employed to do the work with specific skills now use consultants, what then are we employed to do?' (Times 25 March 2015). Perhaps, that is the question that municipal councils and political parties should reflect on, particularly in relative to poor service delivery.

It seems that the politicisation of local government or political involvement is not in itself an issue, but the particular aspect of that involvement is. Politicians can play a role in influencing local government processes positively if they are committed to organisational solutions and promote the institutionalisation of constitutional values and principles. The Mayor of Umtshezi Municipality in KwaZulu-Natal, Cllr. B Dlamini in an interview on 27 March 2015 identified the challenges experienced in local government relative to the political - administrative interface:

- Delays due to political interference that lead to massive service delivery backlogs, e.g. the handing over of housing units after they have been completed. Sometimes, it is a question of politics versus the needy.

- Lack of accountability and poor communication with communities as the 'big man syndrome' kicks in due to local leaders thinking that they have political protection and become untouchable.

- Problems with the political administrative interface, resulting in paralysis as bureaucrats play, instead of implementing the mandate of the political leadership (government) of the day.

- Corruption and fraud, with political 'mandates' that are illegal and have obscure origins leading to, inter alia, negative audit opinions due to poor financial management.

- Violent service delivery protests, which are increasing especially when local government. Elections are drawing near and individual politicians jostle for councillor positions.

- Weak civil society formations that become embedded in the political lives of local leaders instead of holding local government to account; they fight personal battles as proxy for unfair (bordering on illegal) access to power and resources.

- Scarcity of skills leading to limited municipal capacity, in the political and administrative components of the council.

- Political issues both within the municipality and also intergovernmentally impacting negatively on governance and service delivery (Refer also to Booysen 2012a; Reddy 2010; 2015a; Republic of South Africa 2009). 
The ruling party will, in the final analysis, have to bear the costs of these choices as there has been a decline in its voter base in the major metropolitan areas of South Africa. ${ }^{7}$ The urban voter is sophisticated, educated and demanding, and such citizens have choices that they can exercise as a result of their economic status. They are not dependant on the ruling party for an income, be it a state grant or even jobs. The government ushered in the Local Government: Municipal Systems Amendment Act 2011 (Act 7 of 2011) which has prohibited political office-bearers from occupying senior management positions in local government (Tshishonga 2015:131). It was a firm step to ensure that the municipal administration was not subject to any undue political pressure. However, it remains to be seen whether this legislation will have the desired effect when, as Powell (2012:26) points out, a 'post in a municipality is the gateway to a middle-class lifestyle in a city, town or rural area and when the informal rules of the profiteer trump formal processes and the law'. As indicated previously, the challenge in local government is compliance and respect for the law, and more specifically the need to take firm and decisive action which is lacking.

Policies impacting on the budget that are poorly formulated and implemented, more specifically on debt collection and credit control; and the non-adjustment of tariffs, charges and rates to meet increasing expenditure, leads inevitably to a exponentially growing gap between expenditure and revenue. Zybrands (2012:82) believes that this trend has been a popular course of action in manipulating the local electorate and adds that the larger the gap, the more unlikely it can be closed again without major public protests and financial bailing out by the national or provincial spheres of government.

Supply chain management procedures for the provision of municipal goods and services have provided ample opportunities for self-enrichment, patronage and the favouring of family members and friends (Tshishonga 2015). Zybrands (2012:82) is of the view that such activities have been so endemic in local government that drastic measures have to be taken for this state of affairs to be remedied. He adds that possible solutions in addressing this issue include forfeiture of illegal gains and more successful prosecutions. All of this has taken place despite major reform in local government procurement policies and practices (See Reddy \& Wallis 2015b). A key characteristic of aspiring and serving politicians is making unrealistic promises on basic service delivery and the creation of jobs. However, once they are elected, it is very difficult to hold them publicly accountable for their deeds and actions (Thornhill \& Cloete 2014:65). This lack of public accountability by the councillors and the inaction by the municipality quite often leads to violent protests in the form of marches, looting, and even the physical destruction of property. Zybrands (2012:82) points out that in sharp contrast to poor and failing service delivery, there is

7.ANC support in the Johannesburg, Tshwane and Ekurhuleni metropolitan areas is barely more than $50 \%$, and is $48 \%$ in the Nelson Mandela Municipality. There has been a decline in support in all these areas (Habib 2015:17). also needless spending of public funds on non-service delivery issues such as, inter alia, expensive mayoral vehicles, overseas trips and funeral expenses for councillors. Dlamini ([Umvoti Municipality] pers. comm., 27 March 2015, p. 3) points out that the local government establishment is by its very nature political and in reality there is a thin line separating the administrators and the politicians. Local government is the only sphere in South Africa where local communities vote directly for the politicians. Dlamini ([Umvoti Municipality] pers. comm., 27 March 2015, p. 3) adds that direct voting makes local government political in nature but at the same time argues that this is not necessarily a problem, 'as the effective delivery of services depends on people who understand and are loyal to the policies and programmes of the government of the day. No political party in the world can implement its manifesto without loyal troops that understand and subscribe to its principles'. The appointment of functionaries loyal to the ruling party or political party deployment is a global phenomenon; however, it is imperative that such deployees have the requisite qualifications and experience, more specifically in a developing country like South Africa where there are historical backlogs.

There is no doubt that the local government sphere is highly contested in South Africa as it is the site where basic service delivery takes place. According to Ngubane (pers. comm., 26 March 2015), a former Mayor of Umvoti Municipality in KwaZulu-Natal, political parties wish to be seen on the ground:

'they deploy their strong people with political party mandates, to implement party policies and programmes, ... [and] cadre deployment compromises the recruitment of suitably qualified people to do the job.'

He adds that the politicisation of local government works against the mandate of the very constitution that is designed to cater for and protect the citizens of the country. It comprises practice and brings about uneven or poor service delivery, and the exclusion of communities and people not belonging to the party. Politicisation creates an opportunity for corruption in local government, which in turn impacts negatively on service delivery (Reddy 2010; Tshishonga 2015). It would appear that it will take some time before political maturity prevails and service delivery will be accorded a high priority on the municipal agenda.

\section{Enhanced skills and leadership for effective service delivery}

Good leadership in terms of the Batho Pele Principles is a critical component of successful organisations (www.kznhealth. gov.za/bathopele.htm). The comments made by Pretorius and Schurink (2007:23) (quoting a research participant) on staff training and development have considerable relevance because 'in leadership, people that are skilled have got expertise, are capable and confident and got vision, so that in return the people that are recruited to the organisation have the necessary skills, necessary expertise, they share in values of the 
organisation, they are willing to go out and do things, and that is the only way you can enhance service delivery'.

The neglect of the cadre deployment policy has, according to the African National Congress (ANC), contributed to the current challenges and weaknesses experienced faced by the Organisation post-1994, and to this end, the ANC's 4th National Policy Conference reaffirmed that a 'contingent of cadres should be produced who are competent, committed, disciplined and conscientious' (ANC 2012:3). It recommended that ideological, academic and ethical training and political preparation should constitute the basis of 'deployment'. The conference also affirmed that the performance of cadres deployed should be rigorously monitored and evaluated before they are elected or appointed to leadership positions. It emphasised that academic qualifications should be an integral part of cadre deployment (ANC 2012:3). Despite the decisions taken and the recommendations made by the ruling party, there has been very little change and the implications for local government and more specifically service delivery has been disastrous to say the least. The service delivery protests have continued unabated and perhaps the results of the 2016 local government elections will jolt the ruling party to reality.

\section{Way forward: Policy recommendations}

The following firm recommendations are made in chartering a way forward for the post-1994 local government democratisation and decentralisation project in South Africa:

- Some degree of political maturity should be prevalent in municipal councils, more specifically among the different political parties. The critical issues of good governance, best practices and enhanced service delivery should be high on the municipal agenda as opposed to cheap political point scoring and rivalry, which are superfluous at this stage of the country's development;

- Political parties should ensure that municipal functionaries deployed to local government, especially those holding leadership positions, such as mayors, deputy mayors, speakers, municipal managers, and executive and senior managers, are committed and passionate about enhancing service delivery and improving the lives of residents in local communities. More importantly, they should have the requisite skills and be well capacitated for the task on hand;

- There should be respect for law and order by individuals in both the municipalities and local communities in terms of following through with legislation and compliance. Coupled with this respect for the law, there should be the required organisational public accountability to the local communities and ultimately to the political parties. The lack of public accountability and the disregard for law and order is, in fact, the main source of dysfunctionality within municipalities; and

- The local government system has been undergoing a process of continuous institutional restructuring over a 21-year period. The system has to be stabilised and the structures in place need to develop politically and institutionally. The government has unfortunately attempted to address poor municipal leadership through technical interventions, which have by and large not addressed the basic challenges of local government relative to service delivery.

\section{Conclusion}

A major priority following the ushering in of a democratic state was addressing the developmental backlogs, particularly at the local sphere of government. However, two decades on, the issue of service delivery is a very contentious topic that is high on the municipal agenda nationally. Critical questions in this regard, especially in a South African context, are whether there is delivery in relation to certain basic services and what is the quality of the service being provided? There have been several government initiatives introduced to address service delivery challenges and the dysfunctionality of municipalities to date, and none of them have really borne any fruition in terms of responding to the local governance crisis. At the same time, residents in local communities have become very agitated and in some cases have even resorted to violence in expressing their frustration at poor service delivery.

The South African local governance system, if judged according to the legislative and policy framework, can be described as 'world class' internationally; however, to complement that framework, there has to be the requisite human and financial resources committed to the municipal structures and ensuring that the system works. Those responsible for the political deployment of municipal functionaries have to take into account the passion, commitment, competence, qualifications and ethical leadership of those in line to be appointed or elected. Having 'struggle credentials' is not good enough as ANC 'deployees' will be playing a pivotal role in formulating and implementing policies relative to service delivery and development. Such delivery is the essence of developmental local government and it is also a constitutional imperative. In the final analysis, there should be a radical shift from the policy of 'cadre deployment' and political patronage as it violates the essential principles of good local governance.

\section{Acknowledgements Competing interests}

The author declares that he has no financial or personal relationship(s) which may have inappropriately influenced him in writing this article.

\section{References}

African National Congress, 2012, Recommendations from the 4th National Policy Conference, Gallagher Estate, Midrand, Johannesburg, 26-29th June.

Alexander, P., 2010, 'South Africa's service delivery protests: A preliminary analysis', Review of African Political Economy 37(123), 25-40. http://dx.doi. org/10.1080/03056241003637870

Allan, K. \& Heese, K., n.d., Understanding why service delivery protests take place and who is to blame, Municipal IQ, viewed 13 March 2016, from www.municipaliq. co.za

Bekink, B., 2006, Principles of South African local government law, Lexis Nexis Butterworths, Durban. 
Booysen, S., 2012a, 'Sideshow or heart of the matter? Local politics and South Africa's 2011 local government elections', in S. Booysen (ed.), Local elections in South Africa: Parties, people and politics, pp. 1-10, Sun Press, Bloemfontein.

Booysen, S., 2012b, 'Conclusion', in S. Booysen (ed.), Local elections in South Africa Parties, people and politics, pp. 351-359, Sun Press, Bloemfontein.

Cameron, R., 2003, 'Politics-administrative interface: The case of the city of Cape Town', International Review of Administrative Sciences 69, 51-66, http://dx doi. org/10.1177/0020852303691004

Cameron, R., 2010, 'Redefining political-administrative relationships in South Africa', International Review of Administrative Sciences 76, 676-711. http://dx do org/10.1177/0020852310381204

Carrim, Y., 2010, Towards better understanding of the service delivery protests National Council of Provinces, Department of Co-operative Governance and Traditional Affairs Budget Vote, Cape Town.

Chen, L., Dean, J., Frant, J. \& Kumar, R., What does 'service delivery' really mean in South Africa?, viewed 29 September 2014, from http://blogs.cfr.org/ cambell/2014/05/15south-africa-what-does-service-delivery-really-mean/

Dassah, M.O., 2012, 'A critical analysis of factors underlying service delivery protests in South Africa', Journal of African and Asian Local Government Studies 1(2), 1-28.

De Visser, J., 2005, Developmental local government: A case study of South Africa, Intersentia Publishers, Antwerpen.

De Visser, J., 2010, 'The political-administrative interface in South African municipalities: Assessing the quality of local democracies', Commonwealth Journal of Local Governance, Special Issue, March, 86-101.

Duncan, J., 2009, 'Desperately seeking depth: The media and the 2009 elections', in R. Southall \& J. Daniels (eds.), Zunami: The South African elections of 2009, pp. 133-154, Jacana, Sunnyside.

Govender, J. \& Reddy, P.S., 2012, 'Failing the public through public policy: A review of the local government experience in South Africa', African Journal of Public Affairs 5(1), 69-82.

Habib, A., 2015, 'Send in the competent in place of the Cadres', Sunday Times, 4 January 2015, p. 17.

Ndudula, M.R., 2013, 'An analysis of the politics-administrative interface and its impact on delivery of municipal services: A case of the Mnquma Local Municipality', MPA Dissertation, University of Fort Hare, Alice.

Pieters, B.G. \& Pierre, J., 2004, 'Politicisation of the civil service: Concepts, causes and consequences', in B.G. Pieters \& J. Pierre (eds.), Politicisation of the civil service in comparative perspective, pp. 41-54, Routledge, London.

Pieterse, E., Parnell, S., Swilling, M., van Donk, M., 2008, 'Consolidating developmenta local government', in M. van Donk, M. Swilling \& E. Pieterse (eds.), Consolidating developmental local government: Lessons from the South African experience, pp. 2-23, Isandla Institute, Cape Town.

Powell, D., 2012, 'Imperfect transition - Local government reform in South Africa (1994-2012)', in S. Booysen (ed.), Local elections in South Africa: Policies, parties and politics, pp. 11-30, Sun Press, Bloemfontein.
Pretorius, D. \& Schurnik, W., 2007, 'Enhancing service delivery in local government: The case of a district municipality', South African Journal of Human Resources Management 5(3), 19-29. http://dx.doi.org/10.4102/sajhrm.v5i3.148

Ramjee, M. \& Van Donk, M., 2011, Introduction: Recognising community voice and dissatisfaction, Good Governance Learning Network, Cape Town.

Reddy, P.S., 2010, 'Democratic decentralisation and local democracy in South Africa re-examined: Quo Vadis?', Politeia: South African Journal for Political Science and Public Administration 29(3), 66-87.

Reddy, P.S., 2015a, 'Post local governance and development in South Africa: Quo Vadis?', in P.S. Reddy \& M. De Vries (eds.), Quo Vadis?: Local governance and development in South Africa post 1994, pp. 328-329, Bruylant Publishers, Belgium

Reddy, P.S. \& Naidu, R.A., 2012, 'Development and local governance: The South African experience', in B.S. Baviskar \& A.N. Roy (eds.), Local governance: A global perspective, pp. 107, Ministry of Information and Broadcasting, Government of India, New Delhi.

Reddy, P.S. \& Wallis, M., 2015b, 'Involving SMMEs', in P.S. Reddy \& M. De Vries (eds.), Quo Vadis?: Local governance and development in South Africa post 1994, pp. 237-259, Bruylant Publishers, Belgium.

Republic of South Africa, Constitution of the Republic of South Africa Act, 1996 (Act 108 of 1996).

Republic of South Africa, 2009, State of local government: Overview report: National State of Local Government Assessments, Department of Co-operative Governance and Traditional Affairs, Pretoria.

Times, 15 March 2015. 'JZ : If I were a Dictator', p. 4.

Thornhill, C., 2012, 'Effective political-administrative relationships for policymaking and implementation', African Journal of Public Affairs 5(1), 56-68.

Thornhill, C. \& Cloete, J.J.N., 2014, South African municipal government and administration, Van Schaik Publishers, Pretoria.

Tshishonga, N., 2015, 'The increased politicisation of human resources recruitment' in P.S. Reddy \& M. De Vries (eds.), Quo Vadis?: Local governance and development in South Africa post 1994, pp. 129-146, Bruylant Publishers, Belgium.

Van der Waldt, G., 2014a, 'Fostering local democracy', in G. Van der Waldt et al. (eds.), Municipal management: Serving the people, pp. 23-51, Juta and Company, Cape Town.

Van der Walt, C., 2014b, 'Municipal structures', in G. Van der Waldt et al. (eds.) Municipal management: Serving the people, pp. 73-87, Juta and Company, Cape Town.

Batho Pele: People First: Batho Pele Principles in IsiZulu, viewed 14 August 2015, from www.kznhealth.gov.za/bathopele.htm

Zybrands, W., 2012, 'Municipal structures and finances - Predicaments and performance challenges', in S. Booysen (ed.), Local elections in South Africa: Policies, parties and politics, pp. 67-88, Sun Press, Bloemfontein. 